University of Nebraska - Lincoln

DigitalCommons@University of Nebraska - Lincoln

Faculty Publications: Department of

Entomology

Entomology, Department of

September 1988

\title{
Voltinism and the Induction of Aestival Diapause in the Colorado \\ Potato Beetle, Leptinotarsa decemlineata (Coleoptera: Chrysomelidae)
}

\author{
Maurice J. Tauber \\ Cornell University \\ Catherine A. Tauber \\ Cornell University \\ John J. Obrycki \\ Cornell University \\ Brian Gollands \\ Cornell University \\ Robert J. Wright \\ University of Nebraska-Lincoln, rwright2@unl.edu
}

Follow this and additional works at: https://digitalcommons.unl.edu/entomologyfacpub

Part of the Entomology Commons

Tauber, Maurice J.; Tauber, Catherine A.; Obrycki, John J.; Gollands, Brian; and Wright, Robert J., "Voltinism and the Induction of Aestival Diapause in the Colorado Potato Beetle, Leptinotarsa decemlineata (Coleoptera: Chrysomelidae)" (1988). Faculty Publications: Department of Entomology. 109.

https://digitalcommons.unl.edu/entomologyfacpub/109

This Article is brought to you for free and open access by the Entomology, Department of at DigitalCommons@University of Nebraska - Lincoln. It has been accepted for inclusion in Faculty Publications: Department of Entomology by an authorized administrator of DigitalCommons@University of Nebraska - Lincoln. 


\title{
Voltinism and the Induction of Aestival Diapause in the Colorado Potato Beetle, Leptinotarsa decemlineata (Coleoptera: Chrysomelidae)
}

\author{
MAURICE J. TAUBER, CATHERINE A. TAUBER, JOHN J. OBRYCKI, ${ }^{1}$ \\ BRIAN GOLLANDS, AND ROBERT J. WRIGHT ${ }^{2}$
}

Department of Entomology, Comstock Hall, Cornell University, Ithaca, New York 14853

\begin{abstract}
Ann. Entomol. Soc. Am. 81(5): 748-754 (1988)
ABSTRACT Field studies over $3 \mathrm{yr}$ demonstrated that overwintering populations of the Colorado potato beetle in upstate New York and on Long Island are composed of adults from both the first and second summer generations. The two populations from the climatically different regions differ in their responses to environmental factors that influence voltinism. The critical photoperiod for aestival diapause induction is longer, and the induction of diapause by low temperature is greater, in the population from the cooler, inland locality (upstate New York) than in the population from the warm coastal area (Long Island). Under the long days of early summer, temperature appears to influence aestival diapause induction and voltinism at both localities. A large proportion of first-generation adults enters diapause either without ovipositing or after ovipositing for a brief period. These responses have significance for the evolution of the beetle's life history and for its population dynamics and management.
\end{abstract}

KEY WORDS Insecta, phenology, aestivation, photoperiod

KNOWLEDGE of the primary factors that influence phenological traits is essential for understanding evolutionary adaptations to temporally and spatially varying habitats. It is also essential for predicting development and activity in the field, and, in the case of economic pests, for developing longterm, reliable methods for management. Although many significant phenological characteristics of the Colorado potato beetle, Leptinotarsa decemlinea$t a$ (Say), are known (see specifics below), vital questions remain regarding the timing and number of summer generations, the occurrence of aestival diapause in North America, and the contribution that the early and late-summer generations make to the overwintering population.

A variety of factors can interact to influence voltinism and imaginal diapause in the Colorado potato beetle. Pioneering work by European workers elucidated the behavioral and physiological characteristics of diapause and the important role of photoperiod in diapause induction (Jermy \& Saringer 1955; Goryshin 1956, 1958; de Wilde et al. 1959; Minder \& Kozarzhevskaya 1966; Ushatinskaya 1966; Hodek 1971; deKort et al. 1980; deKort 1981; Briers et al. 1982). Subsequent studies reported the critical photoperiod for diapause induction in numerous populations of the beetle from the Old and New World (de Wilde \& Hsiao 1981, Hsiao 1981, Goryshin et al. 1987).

\footnotetext{
Current address: Department of Entomology, Iowa State University, Ames, Iowa 50011 .

${ }^{2}$ Current address: Department of Entomology, University of Nebraska, Lincoln, Nebr. 68583.
}

In addition to photoperiod, food and temperature also influence diapause induction in the Colorado potato beetle. Senescent foliage of the host plant, Solanum spp., and low temperatures were shown to enhance the diapause-inducing effects of photoperiod (Goryshin 1958, de Wilde \& Ferket 1967, de Wilde et al. 1969, Hare 1983). However, with the exception of Goryshin et al. (1987), there are no reports on either geographical variation in the responses to food or temperature, or the extent to which the factors interact to induce diapause in natural populations.

Our purpose here is to compare the critical photoperiods for diapause induction in two populations of the Colorado potato beetle from climatically different regions in New York state, examine the influence of temperature on diapause induction in the two populations, establish whether aestival diapause occurs in the two populations, and determine if the first as well as the second summer generation overwinters.

\section{Materials and Methods}

The two populations we studied were from a warm, coastal area with a relatively long growing season (Riverhead, Long Island, Suffolk County, N.Y.; latitude $40^{\circ} 58^{\prime} \mathrm{N}$ ) and a cool, inland locality with a relatively short growing season (Freeville, Tompkins County, N.Y.; latitude $42^{\circ} 27^{\prime} \mathrm{N}$ ). All our experiments used first-generation offspring of Colorado potato beetle adults collected from these sites. Each pair of adults was maintained in cages ( 0.24 
liter) provided with Solanum tuberosum (cv. Katahdin) foliage at 22 or $24^{\circ} \mathrm{C}$ and a $16: 8$ (L:D) photoperiod. In all our tests, temperature fluctuated $0.5^{\circ} \mathrm{C}$ on either side of the designated constant temperature. Reference specimens from both populations have been deposited in the Cornell University Insect Collection (Lot \#1158).

Reproductive diapause in the Colorado potato beetle involves a variety of behavioral and physiological symptoms (e.g., positive geotaxis, negative phototaxis, digging behavior, lack of reproductive development, enlarged fat body) (de Wilde et al. 1959). We considered diapause to be averted if beetles oviposited within $27 \mathrm{~d}$ of emergence, a period that exceeds the nondiapause preoviposition period by three times (C. A. Tauber et al. 1988). Digging behavior, small ovaries, and enlarged fat body were also considered symptomatic of diapause.

Critical Photoperiod for Diapause Induction. We reared individuals from egg to adult under a range of photoperiods from 10:14 to $16: 8$ (L:D) at $23.9^{\circ} \mathrm{C}$ (Table 1). For each population the experiment was repeated three times. Parental beetles from Freeville came from spring-generation beetles. Adults from Riverhead were from the spring generation (first and third repetitions) or from the late-summer population (second repetition).

All larvae had continuous access to fresh potato foliage; the stems of the foliage were placed in water-filled vials plugged with cotton. First and second instars received young potato foliage; third and fourth instars received bouquets of mediumaged (fully expanded) potato leaves. When larvae molted to the fourth instar, we provided a layer of moistened vermiculite as a medium for pupation.

Newly emerged adults were paired and maintained at their respective photoperiods in cages with moist vermiculite and fresh potato foliage (as above). Beetles that did not reproduce were either held under their respective conditions for approximately $3 \mathrm{mo}$, or they were dissected to determine their reproductive state (i.e., the development of their ovaries and fat body).

Temperature and Diapause Induction. We reared individuals as above under a range of tem-

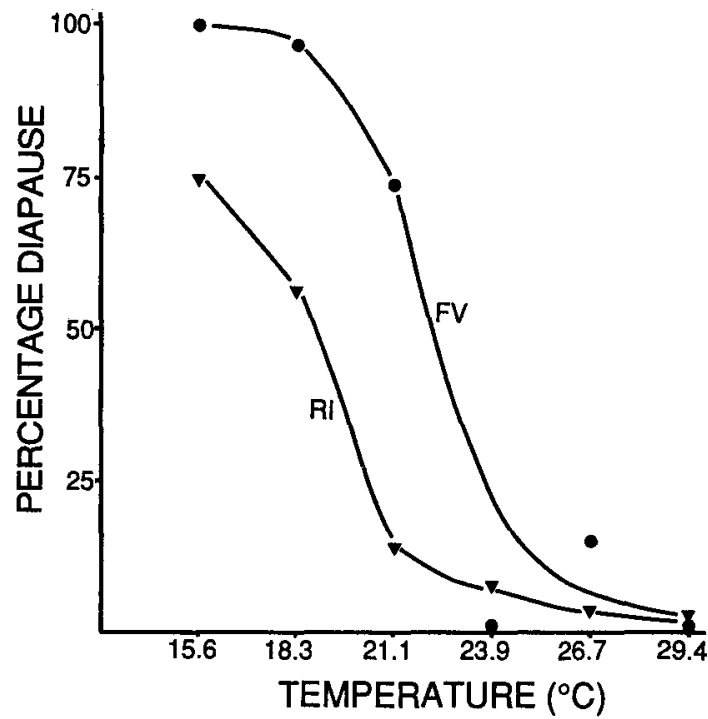

Fig. 1. Influence of temperature on the incidence of diapause in Leptinotarsa decemlineata from two regions of New York state. FV, Freeville, upstate New York; RI, Riverhead, Long Island. L:D 16:8. No. for each data point $=21-35$ (except RI at $15.6^{\circ} \mathrm{C}, n=8$ ).

peratures from 15.6 to $29.4^{\circ} \mathrm{C}$ at $16: 8$ (L:D) (Fig. 1). Each experiment was performed three times for each population; there were no significant differences among repetitions; therefore the data from repetitions were combined. Parental beetles from Freeville consisted of overwintering adults that terminated diapause in the laboratory (first two experiments) or were collected after diapause termination in the spring (third experiment). Adults from Riverhead were dug from the ground in the fall and held until diapause terminated (first experiment), or were collected in the spring (second experiment), or summer (third experiment).

Diapause Induction in the Field. To compare the rates of oviposition and diapause induction in the laboratory with those in the field, we examined the pattern of oviposition and digging by adults throughout three field seasons at Riverhead and four seasons at Freeville. The studies were initiated

Table 1. Photoperiodic induction of diapause in $\mathrm{L}$. decemlineata from two areas in New York (temp $=24^{\circ} \mathrm{C}$ )

\begin{tabular}{|c|c|c|c|c|c|c|}
\hline \multirow{2}{*}{ Locality } & \multicolumn{6}{|c|}{ Photoperiod (L:D) } \\
\hline & $10: 14$ & $12: 12$ & $13: 11$ & $14: 10$ & $15: 9$ & $16: 8$ \\
\hline \multicolumn{7}{|l|}{ Freeville } \\
\hline $\begin{array}{l}\text { Incidence of diapause }(\bar{x} \pm S E \%) \\
\text { No. pairs }\end{array}$ & $\begin{array}{r}100 \\
11\end{array}$ & $\begin{array}{r}100 \\
11\end{array}$ & $\begin{array}{r}100 \\
9\end{array}$ & $\begin{array}{r}100 \\
57\end{array}$ & $91 \pm 8$ & $33 \pm 1$ \\
\hline $\begin{array}{l}\text { Preoviposition period }(\bar{x} \pm S E d) \\
\text { No. pairs }\end{array}$ & - & - & - & - & $10.9 \pm 0.2$ & $\begin{array}{c}8.0 \pm 0.5 \\
37\end{array}$ \\
\hline \multicolumn{7}{|l|}{ Riverhead } \\
\hline $\begin{array}{l}\text { Incidence of diapause }(\bar{x} \pm S E \%) \\
\text { No. pairs }\end{array}$ & $\begin{array}{r}100 \\
44\end{array}$ & $\begin{array}{r}100 \\
44\end{array}$ & $\begin{array}{r}100 \\
31\end{array}$ & $\begin{array}{r}100 \\
52\end{array}$ & $\begin{array}{c}55 \pm 9 \\
39\end{array}$ & $21 \pm 11$ \\
\hline $\begin{array}{l}\text { Preoviposition period }(\bar{x} \pm S E d) \\
\text { No. pairs }\end{array}$ & - & - & - & - & $9.5 \pm 1.7$ & $9.4 \pm 1.0$ \\
\hline
\end{tabular}


Table 2. Behavior of adult $L$. decemlineata under field conditions at Freeville, N.Y.

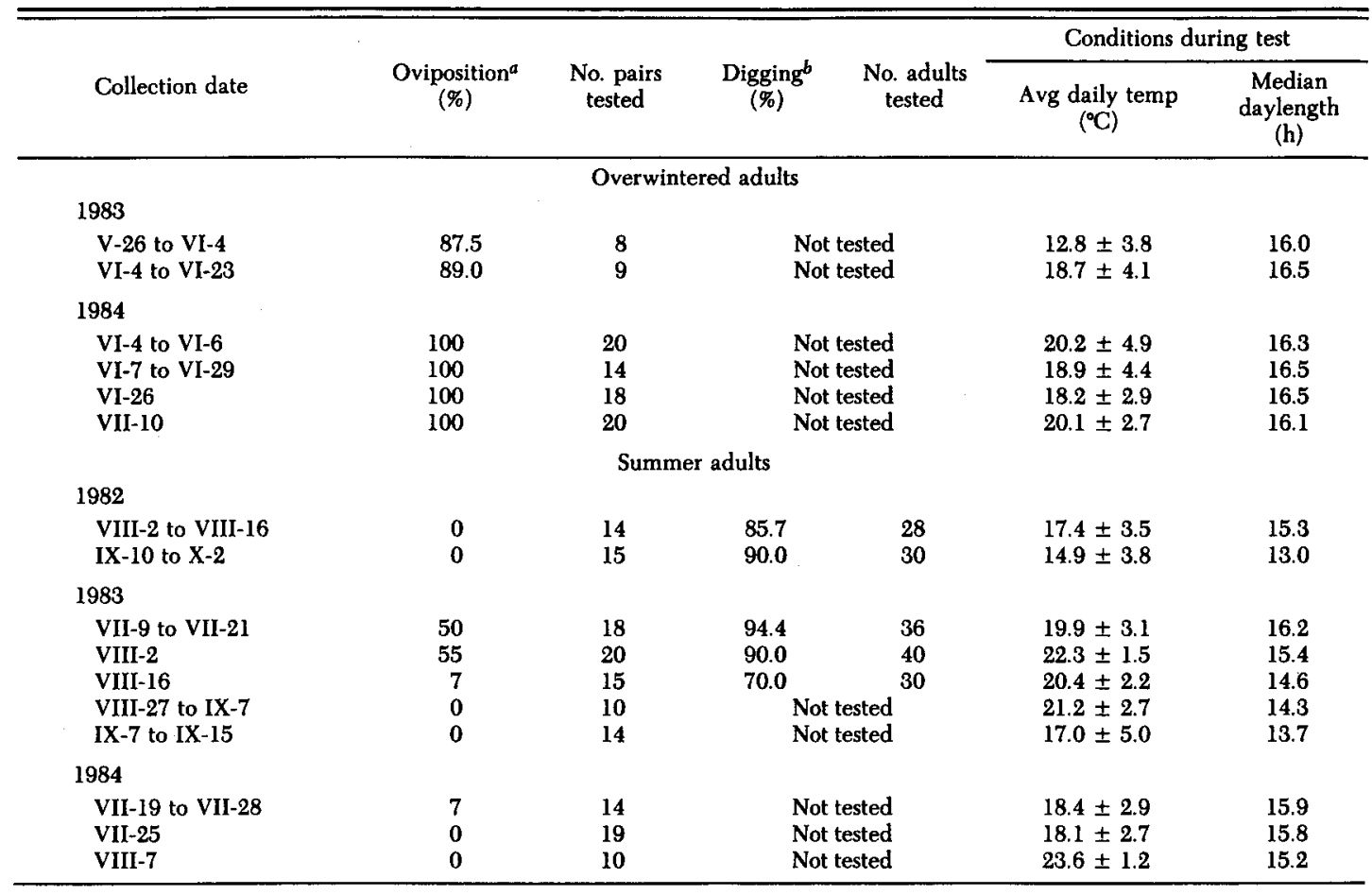

a $\%$ oviposition $=$ no. $\$$ ovipositing/no. $\&$ alive at end of observation period $(1$ wk); includes some $\$ 9$ that entered the substrate after ovipositing.

$b \%$ digging $=$ no. adults observed in substrate sometime during observation period/no. adults alive; may exclude some individuals that dug and reemerged.

at intervals during the summer with field-collected adults. Each pair was maintained for $1-2$ wk in a 0.24 -liter cage and was provided a layer of vermiculite and continuous access to fresh potato foliage. The cages were examined daily for oviposition; digging was recorded daily for the beetles from Freeville and at the end of the experiment at Riverhead. The 0.24 -liter cages were held outdoors in large field cages. Outdoor temperatures were recorded with hygrothermographs in ventilated boxes at the same height as the rearings and near the plots in which we conducted our rearings.

\section{Results}

Critical Photoperiod for Diapause Induction. None of the females reared at photoperiods between 10:14 and 14:10 (L:D) reproduced; they all entered diapause (Table 1). In the Freeville and Riverhead populations, reproduction occurred at $15: 9$ and 16:8 (L:D); however, the incidence of reproductive diapause at $15: 9$ (L:D) (but not 16:8 [L:D]) was significantly higher among the beetles from the Freeville population than from the Riverhead population ( $G$ test adjusted with Williams' correction: $15: 9$ [L:D], G $=15.909, P<0.001 ; 16: 8$ [L:D], $\mathrm{G}=1.499, P>0.1$ ). Thus, at $23.9^{\circ} \mathrm{C}$, the critical photoperiod for diapause induction $(>50 \%$ diapause) is longer for the Freeville population
(15.8:8.2 [L:D]) than for the Riverhead population (15:9 [L:D]). Variation among the repetitions of each experiment was small and unrelated to the origin of the samples (see Lansky 1984).

The average preoviposition period of nondiapausing females (at 16:8 [L:D]) ranged from 8.5 to $9.5 \mathrm{~d}$ (Table 1). There were no significant differences in the preoviposition periods of the Riverhead beetles reared under 15:9 and 16:8 (L:D) $(t$ test with pooled repetitions: $t=-0.063, P=0.950$ ). Similarly, the preoviposition periods of nondiapausing females at 16:8 (L:D) did not differ significantly between populations ( $t$ test with pooled repetitions: $t=1.097 ; P=0.296$ ).

Dissections of nonreproductive beetles showed enlarged fat bodies and poorly developed ovaries. A few of the diapausing beetles that had been held under short daylengths oviposited after $>200 \mathrm{~d}$, but the incidence of postdiapause oviposition was not related to photoperiod. The number of females ovipositing was too low to determine whether there was a relationship between the duration of diapause and photoperiod.

Temperature and Diapause Induction. At 16:8 (L:D), the incidence of diapause induction in the Freeville and Riverhead populations was negatively related to temperature (Fig. 1). Virtually no diapause occurred at $29.4^{\circ} \mathrm{C}$, whereas at $15.6^{\circ} \mathrm{C}$, a high proportion of the beetles entered diapause. 
Table 3. Behavior of adult $L$. decemlineata under field conditions at Riverhead, Long Island, N.Y.

\begin{tabular}{|c|c|c|c|c|c|c|}
\hline \multirow[b]{2}{*}{ Collection date } & \multirow[b]{2}{*}{$\begin{array}{l}\text { Oviposition }{ }^{a} \\
(\%)\end{array}$} & \multirow[b]{2}{*}{$\begin{array}{l}\text { No. pairs } \\
\text { tested }\end{array}$} & \multirow[b]{2}{*}{$\begin{array}{l}\text { Digging } b \\
(\%)\end{array}$} & \multirow[b]{2}{*}{$\begin{array}{l}\text { No. adults } \\
\text { tested }\end{array}$} & \multicolumn{2}{|c|}{ Conditions during test } \\
\hline & & & & & $\underset{\left({ }^{\circ} \mathrm{C}\right)}{\text { Avg daily temp }}$ & $\begin{array}{l}\text { Median } \\
\text { daylength } \\
\text { (h) }\end{array}$ \\
\hline \multicolumn{7}{|c|}{ Overwintered adults } \\
\hline 1983 (VII-1) & 93 & 15 & 0 & 14 & $21.1 \pm 2.8$ & 16.0 \\
\hline $1984(\mathrm{VI}-20)$ & 70 & 20 & 17 & 6 & $18.9 \pm 0.9$ & 16.3 \\
\hline \multicolumn{7}{|c|}{ Summer adults } \\
\hline \multicolumn{7}{|l|}{1982} \\
\hline VIII-2 & $0^{c}$ & 10 & 0 & 19 & $23.5 \pm 1.2$ & 15.5 \\
\hline VIII-9 & $0^{c}$ & 9 & 0 & 16 & $23.6 \pm 2.1$ & 15.1 \\
\hline VIII-16 & 25 & 8 & 79 & 14 & $23.1 \pm 1.8$ & 14.8 \\
\hline VIII-23 & 11 & 9 & 61 & 18 & $21.5 \pm 1.2$ & 13.8 \\
\hline IX-7 & 0 & 9 & 32 & 19 & $19.3 \pm 1.9$ & 13.6 \\
\hline IX-13 & 0 & 8 & 65 & 17 & $18.9 \pm 2.0$ & 13.0 \\
\hline \multicolumn{7}{|l|}{1983} \\
\hline VII-15 & $22^{c}$ & 18 & 59 & 29 & $23.7 \pm 1.2$ & 15.8 \\
\hline VII-29 & $16^{c}$ & 19 & 56 & 34 & $23.1 \pm 1.2$ & 15.4 \\
\hline VIII-13 & 6 & 17 & 85 & 27 & $18.6 \pm 3.3$ & 14.3 \\
\hline VIII-26 & 11 & 19 & 79 & 38 & $20.9 \pm 1.6$ & 14.0 \\
\hline IX-11 & $\mathbf{0}$ & 17 & 69 & 32 & $20.6 \pm 5.2$ & 13.1 \\
\hline \multicolumn{7}{|l|}{1984} \\
\hline VII-19 to VII-24 & $0^{c}$ & 39 & 50 & 18 & $20.7 \pm 1.8$ & 15.7 \\
\hline VIII-30 to IX-1 & 0 & 20 & 90 & 20 & $18.8 \pm 2.8$ & 13.7 \\
\hline
\end{tabular}

$a \%$ oviposition $=$ no. $q$ ovipositing $/$ no. $q$ alive at end of observation period $(1 \mathrm{wk})$; includes some $\%$ that entered the substrate after ovipositing.

$b \%$ digging $=$ no. adults in substrate at end of observation period/no. adults alive; may exclude some individuals that dug and reemerged.

${ }^{c}$ Considerable oviposition occurred in adjacent potato fields at this time; foliage was provided daily to the caged beetles, but sometimes it did not remain in fresh condition when temperatures were high.

Diapause was more common at low temperatures among the beetles from Freeville than those from Riverhead.

Diapause Induction in the Field. During spring at both Freeville and Riverhead, the percentage of overwintered females that oviposited was very high-70-100\% (Tables 2 and 3). Most of these beetles continued to oviposit regularly during the observation period (1-2 wk), and the amount of digging was low.

Our tests with the summer generation at Freeville began during the first 3 wk of July in 1983 and 1984 and during the first week of August in 1982 (Table 2). In both 1982 and 1984, the incidence of oviposition was very low and digging was common, even during the first sample period. However, during 1983 (the warmest of the $3 \mathrm{yr}$ ), the incidence of oviposition in the July and early August samples was approximately $50 \%$; it declined thereafter. The amount of digging by summergeneration beetles was high, indicating that some beetles that oviposited subsequently entered diapause.

The test in 1987 began with teneral adults on 3 August and continued until the end of August. One female from 35 pairs oviposited infertile eggs; the remainder did not oviposit. All the adults dug (temperature 3-17 August, $20.4 \pm 2.8^{\circ} \mathrm{C}$ ).

Our tests with the summer generation at Riverhead began in mid-July in 1983 and 1984 and at the beginning of August in 1982 (Table 3). At these times there was considerable oviposition in potato fields; however, few of the early summergeneration females oviposited in the cages adjacent to the fields. The rates of oviposition in our tests may have been low because the caged beetles did not have continuous access to fresh foliage; during very warm weather, feeding rates were very high, and the beetles often severed leaves from stems. As a result, the foliage wilted and the adults were left for much of the day without adequate food. Thus, the low level of oviposition in our cages did not fully reflect the natural situation.

Except for the first two samples from the summer generation of 1982, all samples showed substantial amounts of digging. In addition, some of the beetles that oviposited subsequently dug, indicating that females entered diapause after ovipositing.

\section{Discussion}

The photoperiodic response curves of $L$. decemlineata from Long Island (Riverhead) and upstate New York (Freeville) are generally very similar to those reported for populations from Europe and western United States; i.e., the incidence of diapause is high at 14:10 (L:D) and relatively low at 16:8 (L:D) (Goryshin 1956, 1958; de Wilde \& Hsiao 1981; Hsiao 1981; Goryshin et al. 1987). The two 
populations we tested differed in their responses to 15:9 (L:D); individuals from Freeville are more likely to enter diapause under this daylength than those from Riverhead. Thus, the critical photoperiods of the two populations fall slightly below the longest day of the year (including civil twilight) at their respective localities.

Although the two populations in New York differ in their critical photoperiods for diapause induction, the seasonal cycles at Riverhead and Freeville are not entirely determined by photoperiod. Diapause occurred in many adults that emerged in early to midsummer when daylengths (including civil twilight) were longer than the critical photoperiod and when host plants were available. Our findings help explain this observation. Temperatures below $26^{\circ} \mathrm{C}$ increase the incidence of diapause at 16:8 (L:D). This effect is greater among beetles from Freeville than those from Riverhead, a situation that is consistent with the geographical differences in the timing and incidence of aestival diapause. The longer critical photoperiod and the lower thermal threshold for diapause induction in beetles from Freeville may account for the high incidence of diapause induction by first-generation beetles at Freeville.

The European literature dealing with the phenology of the Colorado potato beetle contains several references to aestival diapause (e.g., Jermy \& Saringer 1955, de Wilde 1969, Minder \& Petrova 1976, Ushatinskaya 1976, Goryshin et al. 1987). However, reports of aestival diapause are generally lacking or anecdotal for populations from North America (e.g., Fink 1925, Gibson et al. 1925). The single experimental consideration of aestival diapause in North American field populations implicates the host plant as a major inducing factor (Hare 1983). Voltinism and the incidence of reproductive diapause differed between beetles reared and maintained on Solanum dulcamara and S. tuberosum. These experiments were largely conducted outdoors during June and July in Connecticut, and no aestival diapause was reported for beetles reared and maintained on S. tuberosum (cv. Katahdin).

Unlike Hare (1983), we found that many firstgeneration adults (reared on potato) entered diapause. A substantial number of these did so after ovipositing briefly. Because populations of the Colorado potato beetle at Riverhead and Freeville are generally large, nondiapause or prediapause oviposition by even a small proportion of first-generation females can result in large populations of second-generation larvae in the field. This situation tends to obscure the seasonal behavior of summer beetles, and it helps explain why aestival induction of diapause has gone unreported in North America.

Observations of caged beetles in the field indicate that diapausing beetles do not reemerge from the soil to oviposit or disperse in late summer or fall. Therefore, we conclude that the overwintering populations at Freeville and at Riverhead comprise adults from both the first and second summer generations.

At both localities, especially Freeville, the between-year variation in oviposition was generally related to summer temperatures in the field (Tables 2 and 3 ). This suggests that temperature, as well as food, has a major role in regulating the incidence of oviposition and the timing of diapause induction in the summer generation of beetles.

Life-history Implications. Variability in voltinism constitutes an effective means for insects to cope with unpredictable deterioration of environmental conditions. Insects accomplish this through two mechanisms (Tauber et al. 1986). First, they may evolve means for anticipating and responding to cues that herald imminent adversity (e.g., response to senescing foliage). Second, they may evolve polymorphisms for the timing of diapause (e.g., Istock 1981). Hare's (1983) study and ours demonstrate that the Colorado potato beetle uses the first mechanism; it responds to the immediate conditions of low temperature and senescing foliage by entering diapause. However, we suggest that the beetle also uses the second mechanism as well, because there is intrapopulation variation in the beetle's responsiveness to diapause-inducing factors. As a result, diapause induction begins in a part of the population very early in the summer and extends over a broad period.

In many respects, the Colorado potato beetle appears to have evolved a wide range of options in its seasonal life cycle. On the one hand, diapause induction early in the summer provides a very conservative life-history pathway that protects the beetle from catastrophic changes in the habitat. In most insects, this alternative is associated with considerable reproductive cost-the postponement of reproduction for an entire year. However, firstgeneration beetles circumvent this extreme tradeoff between diapause and reproduction by mating and ovipositing for a short period before entering diapause. If environmental conditions remain favorable, the second-generation offspring can complete development and join their parents in the overwintering population.

Pest Management Implications. These findings have several practical implications for the population dynamics and management of the Colorado potato beetle. First, defoliation by the beetle affects potato yield most severely when it occurs at the middle of the season-the time corresponding to emergence, feeding, and oviposition by summer adults (Hare 1980). These events are predictable, in part, by monitoring temperatures during spring and early summer (see C. A. Tauber et al. 1988, M. J. Tauber et al. 1988). If the rates of feeding by prediapause and nondiapause adults differ, the amount of significant defoliation may be related to the level of diapause induction in the first summer generation. This, too, is predictable, at least in part, by monitoring temperature and host quality. 
Second, various agronomic practices that reduce late-season food sources for adults and larvae (e.g., use of early maturing varieties and vine-killing) have been proposed for controlling Colorado potato beetles. Because of the great variability in timing of potato beetle diapause induction, a significant proportion of adults from the first generation will have entered diapause and escaped to the soil by the time these measures are taken. Therefore, these agronomic practices will probably have their greatest influence on second-generation larvae and adults, which would otherwise complete development and enter diapause later in the season.

Third, the fact that adults of first and second summer generations enter diapause has important implications for the population dynamics of the Colorado potato beetle; this factor should be incorporated into population models of the beetle (Voss et al. 1988). It should also be included in considerations of the beetle's evolution of resistance to pesticides, a very severe problem. Exposure to pesticides and the resulting selection pressure for resistance may differ between the first and second generations. However, adults from both generations combine to become the overwintering population. Therefore, the maintenance of genetic variability for pesticide susceptibility or resistance may be closely related to the phenology of local populations.

\section{Acknowledgment}

We thank Ward M. Tingey, Cornell University, for his cooperation and comments on an earlier draft, and an anonymous reviewer for suggestions. Some of the laboratory data from the Long Island population are based on M.S. thesis research conducted in our laboratory by David M. Lansky (1984). The work was carried out in conjunction with regional cooperative project NE 154 and supported in part by USDA Competitive Grants \#87-CRCR-1-2376 and \#7800454 and subsequent renewals. We acknowledge CALS IPM program and the Office of Research, Cornell University Agricultural Experiment Station, which provided partial support for J.J.O.

\section{References Cited}

Briers, T., M. Peferoen \& A. de Loff. 1982. Ecdysteroids and adult diapause in the Colorado potato beetle, Leptinotarsa decemlineata. Physiol. Entomol. 7: 379-386.

de Kort, C. A. D. 1981. Hormonal and metabolic regulation of adult diapause in the Colorado beetle, Leptinotarsa decemlineata (Coleoptera: Chrysomelidae). Entomol. Gen. 7: 261-271.

de Kort, C. A. D., H. Schooneveld \& J. de Wilde. 1980. Endocrine regulation of seasonal states in the Colorado potato beetle, Leptinotarsa decemlineata, pp. 233-240. In A. K. Minks \& P. Gruys [eds.], Integrated control of insect pests in the Netherlands. Wageningen Cent. Agr. Publ. Documentation, Wageningen, The Netherlands.

de Wilde, J. 1969. Diapause and seasonal synchronization in the adult Colorado beetle (Leptinotarsa decemlineata Say), pp. 263-284. In H. W. Woolhouse [ed.], Dormancy and survival. Symposia of the Society for Experimental Biology 23. Academic, New York.

de Wilde, J. \& P. Ferket. 1967. The hostplant as a source of seasonal information. Meded. Fac. Landbouwwet. Rijksuniv. Gent 32: 387-392.

de Wilde, J. \& T. Hsiao. 1981. Geographic diversity of the Colorado potato beetle and its infestation in Eurasia, pp. 47-68. In J. H. Lashomb \& R. Casagrande [eds.], Advances in potato pest management. Hutchinson Ross, Stroudsburg, Pa.

De Wilde, J., C. S. Duintjer \& L. Mook. 1959. Physiology of diapause in the adult Colorado beetle (Leptinotarsa decemlineata Say) - I. The photoperiod as a controlling factor. J. Insect Physiol. 3: 75-85.

de Wilde, J., W. Bongers \& H. Schooneveld. 1969. Effects of hostplant age on phytophagous insects. Entomol. Exp. Appl. 12: 714-720.

Fink, D. E. 1925. Physiological studies on hibernation in the potato beetle, Leptinotarsa decemlineata Say. Biol. Bull. 49: 381-406.

Gibson, A., R. P. Gorham, H. F. Hudson \& J. A. Flock. 1925. The Colorado potato beetle in Canada. Canada Department of Agriculture Bulletin 52.

Goryshin, N. I. 1956. The photoperiodic reaction in the Colorado beetle (Leptinotarsa decemlineata Say). Rep. Acad. Sci. USSR 109: 205-208 (reported in A. S. Danilevskii, 1965. Photoperiodism and seasonal development of insects. Oliver \& Boyd, Edinburgh).

1958. The effect of day-length on the onset of diapause in the Colorado beetle (Leptinotarsa decemlineata Say). In The Colorado beetle. Acad. Sci. USSR, M, 2: 136-149 (reported in A. S. Danilevski, 1965. Photoperiodism and seasonal development of insects. Oliver \& Boyd, Edinburgh).

Goryshin, N. I., T. V. Volkovich, A. K. Saulich \& N. N. Shakhova. 1987. Comparative-ecological study of Colorado potato beetle, Leptinotarsa decemlineata Say (Coleoptera, Chrysomelidae) populations of the European part of the USSR. Entomol. Rev. 66: 131142.

Hare, J. D. 1980. Impact of defoliation by the Colorado potato beetle on potato yields. J. Econ. Entomol. 73: 369-373.

1983. Seasonal variation in plant-insect associations: utilization of Solanum dulcamara by Leptinotarsa decemlineata. Ecology 64: 345-361.

Hodek, I. 1971. Sensitivity of larvae to photoperiods controlling the adult diapause of two insects. J. Insect Physiol. 17: 205-216.

Hsiao, T. 1981. Ecophysiological adaptations among geographic populations of the Colorado potato beetle in North America, pp. 69-85. In J. H. Lashomb \& R. Casagrande [eds.], Advances in potato pest management. Hutchinson Ross, Stroudsburg, Pa.

Istock, C. A. 1981. Natural selection and life history variation: theory plus lessons from a mosquito, pp. 113-127. In R. F. Denno \& H. Dingle [eds.], Insect life history patterns. Springer-Verlag, New York.

Jermy, T. \& G. Y. Saringer. 1955. Die Rolle der Photoperiode in der Auslösung der Diapause des Kartoffelkäfers (Leptinotarsa decemlineata Say) und des amerikanischen weissen Bärenspinners (Hyphantria cunea Drury). Acta Agron. Acad. Sci. Hung. 5: 419440.

Lansky, D. M. 1984. Phenology of the Colorado potato beetle (Leptinotarsa decemlineata) population on Long Island: prediapause development and hibernation. M.S. thesis, Cornell University, Ithaca, N.Y. 
Minder, I. F. \& E. F. Kozarzhevskaya. 1966. Ecology of winter diapause of Colorado beetle, pp. 59-93. In K. V. Arnoldi [ed.], Ecology and physiology of diapause in the Colorado beetle. Izdatel'stvo "Nauka," Moscow (English translation, Indian National Documentation Centre, New Delhi, 1976).

Minder, I. F. \& D. V. Petrova. 1976. Ecological and physiological characteristics of the summer rest of the Colorado beetle, pp. 257-278. In K. V. Arnoldi [ed.] Ecology and physiology of diapause in the Colorado beetle. Izdatel'stvo "Nauka," Moscow (English translation, Indian National Documentation Centre, New Delhi, 1976).

Tauber, C. A., M. J. Tauber, B. Gollands, R. J. Wright \& J. J. Obrycki. 1988. Preimaginal development and reproductive responses to temperature in two populations of the Colorado potato beetle (Coleoptera: Chrysomelidae). Ann. Entomol. Soc. Am. 81: 755-763.

Tauber, M. J., C. A. Tauber \& S. Masaki. 1986. Seasonal adaptations of insects. Oxford University, New York.
Tauber, M. J., C. A. Tauber, J. J. Obrycki, B. Gollands \& R. J. Wright. 1988. Geographical variation in responses to photoperiod and temperature by Leptinotarsa decemlineata (Coleoptera: Chrysomelidae) during and after dormancy. Ann. Entomol. Soc. Am. 81: 764-773.

Ushatinskaya, R. S. 1966. Various forms of physiological dormancy in the Colorado beetle as one of the reasons for its areal enlargement, pp. 1-27. In K. V. Arnoldi [ed.], Ecology and physiology of diapause in the Colorado beetle. Izdatel'stvo "Nauka," Moscow (English translation, Indian National Documentation Centre, New Delhi, 1976).

Voss, R. H., D. N. Ferro \& J. A. Logan. In press. Role of reproductive diapause in the population dynamics of the Colorado potato beetle (Coleoptera: Chrysomelidae) in western Massachusetts. Environ. Entomol.

Received for publication 15 September 1987; accepted 19 April 1988. 